\title{
UPAYA MENINGKATKAN PRESTASI BELAJAR BAHASA INGGRIS MELALUI MODEL PEMBELAJARAN NUMBERED HEADS TOGETHER (NHT) PADA SISWA KELAS VIII MTSN 1 BAUBAU
}

\author{
RAMLAH \\ MTs Negeri 1 Baubau provinsi Sulawesi Tenggara \\ Email : lala55767@gmail.com
}

\begin{abstract}
ABSTRAK
Penelitian ini bertujuan untuk mengetahui peningkatan prestasi belajar Bahasa Inggris melalui implementasi model pembelajaran Numbered Heads Together (NHT) pada siswa Kelas VIII 3 MTs Negeri 1 Baubau Provinsi Sulawesi Tenggara tahun pelajaran 2019/2020. Penelitian dilakukan pada bulan Januari sampai dengan Juni 2020 di Kelas VIII 3 MTs Negeri 1 Baubau dengan 2 siklus Penelitian Tindakan Kelas (PTK). Berdasarkan penelitian dapat diketahui bahwa penerapan model pembelajaran Numbered Heads Together (NHT) dapat meningkatkan prestasi belajar Bahasa Inggris siswa Kelas VIII 3 MTs Negeri 1 Baubau. Saat siklus I PTK terdapat sebanyak $80,95 \%$ siswa tuntas dan sebanyak $19,05 \%$ siswa belum tuntas. Terdapat peningkatan 47,62\% siswa yang tuntas pada siklus I (dari 33,33\% siswa tuntas saat sebelum PTK menjadi 80,95\% siswa tuntas pada PTK siklus I). Saat siklus II PTK terdapat sebanyak 90,48\% siswa tuntas dan sebanyak 9,52\% siswa belum tuntas. Terdapat peningkatan 9,53\% siswa yang tuntas pada siklus II (dari 80,95\% siswa tuntas pada PTK I menjadi 90,48\% siswa tuntas pada PTK siklus II).
\end{abstract}

Kata Kunci: prestasi belajar, Bahasa Inggris, Numbered heads together

\section{PENDAHULUAN}

Pendidikan diwujudkan dengan proses pembelajaran yang mengusahakan siswa aktif mengembangkan diri agar memiliki pengetahuan dapat mengubah sikap dan tingkah laku menjadi terpelajar serta meningkatkan daya saing globalisasi (Maulidar dkk, 2014). Penyiapan sumber daya manusia yang menguasai keterampilan abad ke-21 akan efektif jika ditempuh melalui jalur pendidikan. Perubahan kurikulum telah dilakukan oleh pemerintah (Redhana, 2019). Salah satu faktor yang mempengaruhi berprestasi atau tidaknya suatu proses pendidikan adalah proses pembelajaran yang berlangsung di kelas. Pembelajaran merupakan suatu sistem instruksional yang mengacu pada seperangkat komponen yang saling bergantung satu sama lain untuk mencapai tujuan. Sebagai sebuah sistem, pembelajaran meliputi suatu komponen, dimana komponen pembelajaran tersebut akan mempengaruhi jalannya pembelajaran (Hamruni, 2012:54). Salah satu komponen penting yang harus diperhatikan secara terus menerus dalam proses pembelajaran adalah guru. Salah satu tugas dan tanggung jawab guru adalah transfer of knowledge, yakni proses mentransfer ilmu pengetahuan, informasi, pengalaman dan pelajaran dari berbagai sumber kepada penerima. Dalam dunia pendidikan transfer of knowledge sangat bemanfaat untuk mencapai tujuan pendidikan yaitu untuk meningkatkan kemampuan dan ketrampilan siswa. Proses transfer knowledge akan berjalan dengan baik apabila terjalin komunikasi yang baik antara guru dan siswa. Guru dalam menyampaikan pelajaran perlu mengamati kondisi siswa, kebutuhan siswa dan gaya belajar masing-masing siswa sehingga mampu menentukan model pembelajaran yang tepat dan menciptakan pembelajaran yang menyenangkan sesuai dengan kebutuhan siswa. Guru merupakan elemen kunci dalam sistem pendidikan, khususnya di sekolah. Semua komponen lain, mulai dari kurikulum, sarana-prasarana, biaya, dan sebagainya tidak akan banyak berarti apabila esensi pembelajaran yaitu interaksi guru dengan siswa tidak berkualitas. Semua komponen lain, terutama kurikulum akan "hidup" apabila dilaksanakan oleh guru. (Mutakin, 2015).

Model Pembelajaran berasal dari dua kata yaitu model dan pembelajaran. Model adalah bentuk mode, bentuk rupa, bentuk contoh (Putra, 2016). Model merupakan kerangka 
konseptual yang digunakan sebagai pedoman dalam melakukan suatu kegiatan (Mulyatiningsih, 2016). Sedangkan pembelajaran atau pengajaran adalah upaya untuk membelajarkan siswa. Belajar dan pembelajaran adalah dua hal yang saling berhubungan erat dan tidak dapat dipisahkan dalam kegiatan edukatif. Belajar dan pembelajaran dikatakan sebuah bentuk edukasi yang menjadikan adanya suatu interaksi antara guru dengan siswa. Kegiatan belajar mengajar yang dilakukan dalam hal ini diarahkan untuk mencapai tujuan tertentu yang telah dirumuskan sebelum pengajaran dilakukan. Belajar dimaknai sebagai proses perubahan perilaku sebagai prestasiinteraksi individu dengan lingkungannya. Perubahan perilaku terhadap prestasi belajar bersifat continiu, fungsional, positif, aktif, dan terarah (Pane, dkk 2017). Untuk mencapai tujuan pembelajaran guru diperlukan model pembelajaran yang tepat, sesuai dengan kondisi siswa, karakteristik mata pelajaran dan fasiltias yang tersedia. Sebagai seorang guru harus mampu memilih model pembelajaran yang tepat bagi siswa. Karena itud alam memilih model pembelajaran, guru harus memperhatikan keadaan atau kondisi siswa, bahan pelajaran serta sumber-sumber belajar yang ada agar penggunaan model pembelajaran dapat diterapkan secara efektif dan menunjang keberprestasian belajar siswa (Sinabariba, 2017).

Guru sebagai pembimbing diharapkan mampu menciptakan kondisi yang strategi yang dapat membuat siswa nyaman dalam mengikuti proses pembelajaran tersebut. Dalam menciptakan kondisi yang baik, hendaknya gurumemperhatikan dua hal: pertama, kondisi internal merupakan kondisi yang ada pada dirisiswa itu sendiri, misalnya kesehatan, keamanannya, ketentramannya, dan sebagainya. Kedua, kondisi eksternal yaitu kondisi yang ada di luar pribadi manusia. Keberprestasian dalam proses pembelajaran di kelas memang tidak semata tergantung guru, tetapi melibatkan banyak faktor, diantaranya keaktifan siswa, tersedianya fasilitas belajar, kenyamanan dan keamanan ruangan kelas dan beberapa faktor lainnya, kendati memang keberadaan guru merupakan faktor penentu dalam menciptakan kondisi pembelajaran yang efektif (Fakhurrazi, 2018).

Model pembelajaran ialah kerangka konseptual dan prosedur yang sistematik dalam mengorganisasikan pengalaman belajar untuk mencapai tujuan belajar tertentu, dan berfungsi sebagai pedoman bagi perancang pengajaran dan para guru dalam merencanakan dan melaksanakan aktivitas belajar mengajar. Untuk membelajarkan siswa sesuai dengan caragaya belajar mereka sehingga tujuan pembelajaran dapat dicapai dengan optimal ada berbagai model pembelajaran. Dalam prakteknya, guru harus ingat bahwa tidak ada model pembelajaran yang paling tepat untuk segala situasi dan kondisi. Oleh karena itu, dalam memilih model pembelajaran yang tepat haruslah memperhatikan kondisi siswa, sifat materi bahan ajar, fasilitas-media yang tersedia, dan kondisi guru itu sendiri (Fathurrohman, 2015: 16). Sebagai salah satu faktor pendukung berprestasinya proses pembelajaran, pendidik perlu membantu siswa untuk meningkatkan prestasi belajar dan keterampilan berpikir kritisnya melalui model pembelajaran yang dapat mendukung siswa untuk belajar secara aktif (Amijaya, 2018). Banyak faktor yang mempengaruhi keberprestasian kegiatan pembelajaran sehingga perlu pemahaman atas semua faktor yang ada agar tujuan pendidikan yang terangkum dalam prestasi belajar siswa dapat dicapai sesuai dengan yang diharapkan. Kesulitan belajar dapat saja datang dari siswa tetapi juga disebabkan oleh faktor lingkungan belajarnya. Kesanggupan siswa untuk memahami pelajaran, ketekunan siswa dan kesempatan yang disediakan untuk mempelajari ruang lingkup materi yang ditentukan juga merupakan faktor yang mempengaruhi prestasi belajar.

Berdasarkan pengamatan dapat diketahui bahwa prestasi belajar mata pelajaran Bahasa Inggris siswa Kelas VIII 3 MTs Negeri 1 Baubau masih kurang memuaskan. Hal ini dapat diketahui dari banyaknya siswa yang belum mencapai nilai Kriteria Ketuntasan Minimal (KKM). Banyaknya jumlah siswa yang memperoleh nilai di bawah KKM dikarenakan kurangnya semangat belajar siswa di dalam mengikuti proses pembelajaran di kelas. Hal ini dapat dilihat dari tanda-tanda yang timbul seperti: siswa sering menguap ketika guru sedang menjelaskan materi pelajaran di depan kelas, siswa sering melamun saat belajar, 
dan siswa cenderung pasif dalam belajar. Beberapa usaha telah dilakukan peneliti untuk mengatasinya siswa yang kurang serius dalam mengikuti proses pembelajaran dengan cara memberi peringatan kepada siswa yang suka menguap dan melamun dalam belajar, tetapi prestasi yang diperoleh tidak dapat juga meningkatkan motivasi belajar siswa serta prestasi belajar siswa.

Untuk mengatasi permasalahan di atas diperlukan suatu penerapan model pembelajaran yang kreatif, inovatif, dan tepat serta sesuai dengan kondisi kelas. Salah satu model pembelajaran yang dapat diterapkan adalah model pembelajaran Numbered Heads Together (selanjutnya disebut NHT). Menurut Lie dalam Nursyamasi, dkk (2016) Numbered Heads Together (NHT) atau kepala bernomor adalah suatu tipe dari pengajaran kooperatif pendekatan struktural yang memberikan kesempatan kepada siswa untuk saling membagikan ide-ide dan mempertimbangkan jawaban yang paling tepat. Selain itu, Numbered Heads Together juga mendorong siswa untuk meningkatkan semangat kerjasama mereka. Model ini dapat digunakan untuk semua mata pelajaran dan untuk semua tingkatan siswa. Satu aspek penting dalam pengajaran kooperatif adalah bahwa disamping pengajaran kooperatif membantu mengembangkan tingkah laku kooperatif dan hubungan yang lebih baik diantara siswa, pengajaran kooperatif secara bersamaan membantu siswa dalam pengajaran akademis mereka. Strategi pembelajaran Numbered Heads Together (NHT) terdiri atas empat tahap, yaitu penomoran, pengajuan pertanyaan, berpikir bersama, dan pemberian jawaban (Trianto, 2007: 75). Menurut Zuhdi (2010) adapun kelebihan Numbered Heads Together (NHT) adalah setiap siswa menjadi siap semua, dapat melakukan diskusi dengan sungguh-sungguh, siswa yang pandai dapat mengajari siswa yang kurang pandai.

Alasan dan kelebihan dipilihnya model pembelajaran Numbered Heads Together (NHT) yaitu karena memungkinkan siswa untuk lebih aktif dan bertanggung jawab penuh untuk memahami materi pelajaran baik secara berkelompok maupun individual karena nantinya guru akan memanggil salah satu nomor secara acak untuk mewakili kelompoknya mempresentasekan prestasi pekerjaan kelompoknya, sehingga siswa senantiasa mempersiapkan diri untuk menunjukkan kemampuannya di depan kelas, yang pada akhirnya dapat meningkatkan prestasi belajarnya (Nurmalb, dkk, 2019). Pelaksanaan pembelajaran ini diawali dengan membangun suasana hati siswa agar memiliki perasaan dan pemikiran positif terhadap matematika, memahami materi matematika, mengingat kembali materi yang telah dipelajari, Mendeteksi kesalahan yang dilakukan, mengelaborasi pengetahuan, dan mengulas kembali apa yang telah dikerjakan (Sumartini, 2018).

Prestasi penelitian yang menggunakan model pembelajaran Numbered Heads Together (NHT) menunjukkan bahwa model pembelajaran Numbered Heads Together (NHT) sangat cocok digunakan dalam pembelajaran matematika. Hartanti (2013) menyimpulkan bahwa penggunaan model Numbered Heads Together (NHT) dapat meningkatkan prestasi belajar matematika. Selanjutnya, Sari (2010) menyimpulkan bahwa pembelajaran kooperatif NHT dapat memacu guru dan siswa untuk lebih aktif dalam pembelajaran. Selanjutnya Yansen (2014) menyimpulkan bahwapenerapan model pembelajaran kooperatiftipe NHT dapat meningkatkan prestasi belajar siswa kelas VIIA SMPN 9 Palu dalam menyelesaikan pertidaksamaan linear satu variable.

Berdasarkan hal tersebut maka perlu dilakukan penelitian untuk mengetahui peningkatan prestasi belajar Bahasa Inggris melalui implementasi model pembelajaran Numbered Heads Together (NHT) pada siswa Kelas VIII 3 MTs Negeri 1 Baubau provinsi Sulawesi Tenggara tahun pelajaran 2019/2020.

\section{METODE PENELITIAN}

Penelitian ini dilaksanakan di Kelas VIII 3 MTs Negeri 1 Baubau provinsi Sulawesi Tenggara tahun pelajaran 2019/2020, yaitu dari bulan Januari sampai dengan bulan Juni 2020. Penelitian ini merupakan Penelitian Tindakan Kelas (PTK) yaitu suatu penelitian yang dilakukan di dalam kelas, guna memperbaiki proses pembelajaran yang dilakukan oleh guru 
(Arikunto, 2006). Penelitian ini dilakukan dalam 2 siklus dengan masing-masing prosedur yaitu perencanaan, pelaksanaan, observasi, dan refleksi.

Subjek penelitian ini adalah siswa kelas VIII 3 MTs Negeri 1 Baubau dengan jumlah siswa 42 orang dengan rincian yaitu 20 orang siswa perempuan dan 22 orang siswa laki-laki yang memiliki kemampuan heterogen.

\section{HASIL DAN PEMBAHASAN}

\section{A. Hasil}

Penelitian ini dilaksanakan di kelas VIII 3 MTs Negeri 1 Baubau semester genap Tahun Pelajaran 2019/2020 dengan jumlah siswa 42 orang yang terdiri dari 20 orang siswa perempuan dan 22 orang siswa laki-laki yang mempunyai kemampuan heterogen. Penelitian ini dibagi ke dalam dua siklus.

Tabel 1. Prestasi Belajar Siswa Sebelum PTK

\begin{tabular}{ll}
\hline Nilai Tertinggi & $\mathbf{9 4}$ \\
\hline Nilai Terendah & 60 \\
\hline Rata-Rata & 73,21 \\
\hline Tuntas & 14 orang \\
\hline Tidak Tuntas & 28 orang \\
\hline
\end{tabular}

Berdasarkan tabel tersebut di atas dapat diketahui bahwa sebelum pelaksanaan PTK terdapat sebanyak 33,33\% siswa tuntas dan sebanyak 66,66\% siswa belum tuntas.

Tabel 2. Prestasi Belajar Siswa Siklus I dan Siklus II

\begin{tabular}{lll}
\hline Siklus & Siklus Pertama & Siklus Kedua \\
\hline Nilai Tertinggi & 95 & 95 \\
\hline Nilai Terendah & 67 & 67 \\
\hline Rata-Rata & 78,54 & 80,28 \\
\hline Tuntas & 34 orang & 38 orang \\
\hline Tidak Tuntas & 8 orang & 4 orang \\
\hline
\end{tabular}

Berdasarkan tabel tersebut di atas dapat diketahui bahwa saat siklus I PTK terdapat sebanyak $80,95 \%$ siswa tuntas dan sebanyak $19,05 \%$ siswa belum tuntas. Terdapat peningkatan 47,62\% siswa yang tuntas pada siklus I (dari 33,33\% siswa tuntas saat sebelum PTK menjadi 80,95\% siswa tuntas saat PTK siklus I). Berdasarkan tabel tersebut dapat diketahui bahwa saat siklus II PTK terdapat sebanyak 90,48\% siswa tuntas dan sebanyak 9,52\% siswa belum tuntas. Terdapat peningkatan 9,53\% siswa yang tuntas pada siklus II (dari $80,95 \%$ siswa tuntas pada PTK I menjadi $90,48 \%$ siswa tuntas pada PTK siklus II).

Hal ini menunjukkan bahwa siswa dapat mengikuti proses pembelajaran Bahasa Inggris melalui penerapan model Numbered Heads Together (NHT) dengan sangat baik. Penerapan model pembelajaran Numbered Heads Together (NHT) dapat memperkuat pemahaman siswa karena siswa harus mengemukakan, menjelaskan, memperluas, dan mencatat ide-ide utama dari teks secara verbal. Dalam hal ini, keterampilan memproses informasi lebih diutamakan. Pemprosesan informasi menuntut keterlibatan metakognisi berpikir dan membuat keputusan berdasarkan pemikiran. Selain itu, langkah 'menghubungkan dengan pengalaman' memungkinkan siswa untuk menghubungkan informasi-informasi yang cukup penting dengan pengetahuan yang telah dimiliki sebelumnya.

\section{B. Pembahasan}

Pada pertemuan pertama dengan menerapkan model pembelajaran Numbered Heads Together (NHT) seluruh siswa tidak terlihat antusias. Hal ini terjadi karena siswa tidak 
terbiasa untuk berpikir dan menemukan sendiri. Karena sebelumnya siswa terbiasa menggunakan pembelajaran konvensional yang tidak menuntut siswa untuk berpikir dalam menemukan konsep, serta kurangnya referensi dalam tahap expand (pengembangan). Pada petemuan kedua siswa mulai terbiasa dalam proses pembelajaran Numbered Heads Together (NHT) namun dalam tahap Digest dan Expand siswa masih kesulitan dalam hal memecahkan masalah pada soal karena siswa tidak mau untuk mencari dari sumber lain, namun apabila disuruh mencari menggunakan alat bantu elektronik siswa lebih senang. Pada tahap ini siswa sudah mulai aktif dalam bertanya hal yang belum dipahami. Pada pertemuan ketiga setelah diberikannya kebebasan untuk mencari sumber lain siswa lebih antusias dalam proses pembelajaran dan dalam bertanya maupun menjawab pertanyaan yang diajukan kepada guru, serta setiap tahap pembelajaran siswa lebih aktif dalam setiap kelompoknya.

Berdasarkan proses pembelajaran yang telah dilakukan terlihat bahwa siswa lebih banyak mendapatkan informasi sesuai usaha mereka masing-masing, dan lebih banyak pertanyaan yang muncul sehingga proses pembelajaran lebih menyenangkan. Selain itu, setiap anggota aktif dalam proses pembelajaran, karena masing-masing anggota kelompok mempunyai tugas masing-masing dan juga membantu angota kelompok yang kurang paham dengan materi yang diberikan.

Selain itu, dalam proses pembelajaran menggunakan model pembelajaran Numbered Heads Together (NHT) yang diterapkan menjadikan siswa memiliki aktivitas belajar yang lebih banyak. Siswa juga dapat saling berbagi pengetahuan melalui massing-masing kelompok yang diberikan sehingga memudahkan guru untuk mengecek sejauh mana kemampuan penguasaan materi siswa. Kegiatan pembelajaranpun tidak berpusat pada guru, tetapi dituntut keaktifan siswa sehingga minat siswa dalam pembelajaran lebih besar. Selain itu model pembelarana Numbered Heads Together (NHT) sangat cocok bagi kelas dengan siswa heterogen dan beragam baik dari aspek jenis kelamin maupun kemampuan siswa.

Penerapan model pembelajaran Numbered Heads Together (NHT) dapat mempengaruhi aktivitas siswa dalam mengikuti proses pembelajaran. Siswa yang aktif dapat menciptakan suasana pembelajaran di kelas menjadi lebih menyenangkan. Terciptanya kondisi belajar yang menyenangkan dapat meningkatkan daya serap siswa terhadap meteri ajar yang telah dijelaskan oleh guru, sehingga dapat disimpulkan bahwa penerapan model pembelajaran Numbered Heads Together (NHT) dapat meningkatkan prestasi belajar Bahasa Inggris siswa. Sehingga penerapan model pembelajaran Numbered Heads Together (NHT) dapat meningkatkan prestasi belajar Bahasa Inggris siswa kelas VIII 3 MTs Negeri 1 Baubau Sulawesi Tenggara tahun pelajaran 2019/2020.

\section{KESIMPULAN}

Berdasarkan penelitian dapat diketahui bahwa penerapan model pembelajaran Numbered Heads Together (NHT) dapat meningkatkan prestasi belajar Bahasa Inggris siswa kelas VIII 3 MTs Negeri 1 Baubau Sulawesi Tenggara tahun pelajaran 2019/2020. Saat siklus pertama PTK terdapat sebanyak $80,95 \%$ siswa tuntas dan sebanyak $19,05 \%$ siswa belum tuntas. Terdapat peningkatan $47,62 \%$ siswa yang tuntas pada siklus pertama (dari 33,33\% siswa tuntas saat sebelum PTK menjadi $80,95 \%$ siswa tuntas pada PTK siklus pertama). Saat siklus kedua PTK terdapat sebanyak 90,48\% siswa tuntas dan sebanyak 9,52\% siswa belum tuntas. Terdapat peningkatan 9,53\% siswa yang tuntas pada siklus kedua (dari 80,95\% siswa tuntas pada PTK pertama menjadi 90,48\% siswa tuntas pada PTK siklus kedua).

\section{DAFTAR PUSTAKA}

Amijaya, L. S., Ramdani, A., \& Merta, I. W. (2018). Pengaruh model pembelajaran inkuiri terbimbing terhadap prestasi belajar dan kemampuan berpikir kritis siswa. Jurnal Pijar Mipa, 13(2), 94-99.

Fakhrurrazi, F. (2018). Hakikat pembelajaran yang efektif. At-Tafkir, 11(1), 85-99.

Fathurrohman, M. (2015). Model-Model Pembelajaran. Jogjakarta: Ar-Ruzz Media. 
Fitriana, Sari, F. I. F. I. (2010). Implementasi Model Pembelajaran Kooperatif Tipe Numbered Heads Together (Nht) Untuk Meningkatkan Kemampuan Dalam Pemecahan Masalah Dimensi Tiga Pada Siswa Smk Muhammadiyah 2 Malang (Doctoral dissertation, University of Muhammadiyah Malang).

Hamruni. 2012. Strategi Pembelajaran. Yogyakarta: Insan Madani.

Hartanti, T. (2013). Penggunaan Model Numbered Heads Together (NHT) Dalam Pembelajaran Matematika Di Sekolah Dasar. Kalam Cendekia PGSD Kebumen, 1(1).

Maulidar, N. (2019). Pengaruh Model Pembelajaran Kooperatif Tipe Think Pair Share (TPS) terhadap Kemampuan Pemahaman Konsep Matematis Siswa MTs (Doctoral dissertation, UIN Ar-Raniry Banda Aceh).

Mulyatiningsih, E. (2016). Pengembangan model pembelajaran. Diakses dari http://staff. uny. ac.id/sites/default/files/pengabdian/dra-endang-mulyatiningsihmpd/7cpengembangan-model-pembelajaran. pdf. pada September.

Mutakin, T. Z. (2015). Pengaruh kompetensi, kompensasi, dan latar belakang terhadap kinerja guru. Formatif: Jurnal Ilmiah Pendidikan MIPA, 3(2).

Nurmalb, M. J., Hasbi, M., \& Karniman, T. S. (2019). Penerapan Model Pembelajaran Kooperatif Tipe Numbered Heads Together (Nht) Untuk Meningkatkan Prestasi Belajar Siswa Pada Materi Himpunan. Jurnal Elektronik Pendidikan Matematika Tadulako, 7(1), 60-73.

Nursyamsi, S. Y., Corebima, A. D., \& Susilo, H. (2016). Pengaruh strategi pembelajaran numbered heads together (nht) terhadap prestasi belajar siswa SMA Negeri 1 Muara Badak. Jurnal Pendidikan: Teori, Penelitian, dan Pengembangan, 1(10), 1993-1998.

Putra, F. G. (2016). Pengaruh model pembelajaran reflektif dengan pendekatan matematika realistik bernuansa keislaman terhadap kemampuan komunikasi matematis. $\mathrm{Al}$ Jabar: Jurnal Pendidikan Matematika, 7(2), 203-210.

Redhana, I. W. (2019). Mengembangkan keterampilan abad ke-21 dalam pembelajaran kimia. Jurnal Inovasi Pendidikan Kimia, 13(1).

Sinabariba, R. B. (2017). Peranan guru memilih model-model pembelajaran untuk meningkatkan kemampuan menulis puisi.

Trianto. (2007). Model-model Pembelajaran Inovatif Berorientasi Konstruktivistik. Jakarta: Prestasi Pustaka.

Yansen, I. K. E. (2014). Penerapan Model Pembelajaran Kooperatif Tipe NHT untuk Meningkatkan Prestasi Belajar Siswa pada Materi Pertidaksamaan Linear Satu Variabel di Kelas VII SMPN 9 Palu. Aksioma, 3(2), 97-108.

Zuhdi, A. (2010). Guru Idola. Yogyakarta: Gen-K Publisher. 